\title{
What Have We Got to Lose?
}

Susan Nagelsen

y first experience in the New Hampshire State Prison for Men took
place on a gray January day; the temperature was hovering at three degrees above zero. I arrived for my "training session" with security at one o'clock. I, along with two male colleagues, was here to learn about the inmates we would be teaching. Now, you have to understand that one of my colleagues is a Harley-riding, long-beard-flowing, dressed-all-in-black, professor of literature; a man of "arts and letters" who is known for exclaiming to students "the unexamined life is not worth living," for his never-wavering belief that Marilyn Monroe was and always will be the sexiest woman who ever lived, and for living by the motto "Question Authority." We gathered together, my colleagues and I, in an office with the security officer, and the forty-five minute introductory lesson was off and running. The officer told us, "All inmates are scammers and will do anything they can to take advantage of you." As an aside he offered, "I don't really see why you are doing this." "The Professor" just raised an eyebrow and crossed his arms over his chest as the officer continued. He let us know that we were going to he dealing with the "lowest of the low," and that "there wasn't much hope for them." I sat back in my chair and watched as my colleague began to engage the officer. You see, our resident man of the sixties just could not pass up an opportunity to engage in discourse about the value of learning, of exploring the world around us, of the necessity for humans to look beyond themselves as well as at themselvesall wonderful aspirations worthy of discussion. So he began to talk, to question as only he can, and the officer lost control of his session. When he was finally able to wrestle it back, he looked a bit dazed.

Just as I thought we were going to be allowed out of the office that was getting smaller by the minute, the officer turned to face me. He said there was one last thing that I should know, "Since you're a woman ..." He launched into an oration about what I should do in case there was a riot and I was held hostage. He gave vivid pointers on what to do if I thought I was going to be raped. He said, much to my horror, "The best thing to do is throw-up on your self, that way you'll stink so much they won't want you." The Professor interrupted and said that he thought that would prove highly unnecessary, and the officer said, "Well, that's true, but you can never tell with these people." I seized the opportunity, thankful for the diversion, and told the officer that I 
understood completely. That conversation was done as far as I was concerned. Thus, I was introduced to the underlying hum heard throughout the corrections complex: these people are a waste of time. This philosophy pervades the system; it is the "why-should-they-get-an-education-for-free-when-I-will-have-towork-two-jobs-and-go-into-debt-to-put-my-son/daughter-through-collegeperspective", and I could not have disagreed more completely.

At that time, I had been teaching for fourteen years. I had taught in inner city schools, worked with immigrants, students with specific learning disabilities, students from the barrios of New Mexico, and adults who came to education late in their lives, and I had done just fine. A classroom is a classroom, plain and simple. It does not matter where it is, or who is sitting in those chairs or at those desks. I could not fathom a world as this security officer saw it; I would not believe that this was a waste of my time. In my years of teaching, I have seen students who were culturally deprived. Students who had never been introduced to the world of art, good literature, and philosophy, and whose limited experiences served to hold them in a world of ignorance that often led to anger. These students had walked into my classroom over the years, and I watched as they evolved once their horizons were expanded. I know, without a doubt, that once you open someone's eyes to new ideas, new experiences, once you raise their consciousness, they cannot help but be profoundly changed.

The following Wednesday at around 12:30 in the afternoon, I turned off my car, locked the doors, and made my way toward a system that I knew little about. The NHSP is red brick and razor wire, a throwback to the late 1800s, and on a frigid January afternoon it looked about as bleak as anything could look. I walked up to the door, hit the buzzer, and waited for the lock to click. I walked up a flight of stairs to the waiting officer, just outside the visiting room. He checked my ID and pointed to a door that led to the yard. I looked at him strangely; at least, I am confident that my face must have betrayed my confusion. I expected to be escorted to the classroom, but here he was acting like I was on my own. I had been there once before, with my little group of colleagues, so I thought I could find my way, but ... I headed toward the door, and just as I reached for the knob, he said, "Watch out for the platform; the wind is wicked strong."

I walked out through the door and onto a platform that was open on all sides; this was what would become the education department, but for right now it was a part of the old prison block that had been gutted down to the steel beams. I walked across that platform to the stairs and while it only took twenty 
seconds, I was frozen to the bone. I walked down the stairs and turned left, then I walked down a sidewalk that crossed the open yard. Next came the ramp system that would take me past the chow hall and other doors that led to places I did not need to know about. Then another set of stairs which would take me back down to the yard and from there I would walk the fifty yards to the back door of the industries building. I was clearly in another world, a void, and I could not help but think, as I walked among these incarcerated men, of the words of the security officer. I refused to believe that the faces I saw were unredeemable. I refused to believe that education would make no difference: I held fast to the concept that my students would benefit from this experience, if I could only find my way to the classroom. But, I was nervous. As an outsider, thinking back on the experience, I can tell you that it was surreal.

So the trip in was uncomfortable, but then prison is uncomfortable, so it seemed fitting. I made it to my classroom, and I use that term loosely, in the middle of the industries complex. We were housed in a huge room with open ceilings approximately twenty feet high, and giant fans came on at timed intervals. It was a challenge to battle the fans; in fact, it became comical. They would come on, my voice would rise to overcome the noise; they would stop, my voice would drop, but not always soon enough. What a way to command attention. My first class was filled to the maximum, and when I walked in the door, twenty-three students of varying ages and backgrounds greeted me. I was teaching a required writing class, something that most people would rather avoid. I handed out the syllabus, and as always I heard the groans and moans of my students. My course requires things that students endeavor to avoid at all cost: reading their work out loud, and rewriting. Like most students of writing, they want it to be done perfectly the first time, but that is not possible, for it is the rewriting, the reexamination of our writing that brings the expansion of ideas and the evolution of critical thought. My students would come to embrace this process, but they did not know that yet.

On that cold afternoon, those students and I embarked on a journey, one that would alter each of us, albeit in different ways. I was the guide, but it would be unfair for me to ignore the fact that I learned as much, if not more, than my students, and I am confident that they learned a tremendous amount. My students have often heard me say, "We all have stories to tell." Well, the stories I heard in the five years I taught writing at the "big house" were funny and thoughtful and heartbreaking, and oftentimes filled with recognized human frailty, and the telling of these stories was life altering. Through writing, these 
men analyzed their views, refined philosophical points of view, and came to understand that they had control over their lives. Education is, after all, an empowering experience.

For probably the first time in most of these men's lives, they were being asked to examine with great care some of the most powerful essayists on record. We talked about Martin Luther King's attitudes, about being an oppressed society, and their thoughts on the subject were insightful. We discussed Paulo Freire's Pedagogy of the Oppressed, and I could feel their experiences through their writing; I could see an awakening awareness. They read Alice Walker and Thoreau and E.B. White, and with each piece they read, with each discussion we had, it was obvious that they were beginning to see themselves as students, as writers. Writing by its very nature is difficult because it forces the writer to expose him- or herself by showing the reader how a particular subject is viewed, a task that leaves the author wide open. Students of writing have to be willing to separate personal feelings from their observations, and that is difficult in most circumstances, but these men rose to the occasion in spite of their stultifying surroundings, and the reward for that effort was tremendous growth.

The diligence of the non-traditional students is well-documented, and in the early years of my involvement in this program, before the funding was pulled out from under the wide and varied programs that were available to prisoners, I found students who were hard-working, thoughtful in their writing, and prepared for each and every class. I had to be on my toes with this group. One student, a man doing life without parole, with twenty-six in, had taken it upon himself to learn grammar, and he came to each class with his Warner's in hand, pages marked with questions. In my five-year tenure, even after he could no longer afford to take classes, I never saw him without a book in his hand and a question on his lips. He is a life-long learner, someone who has spent his entire adult life in a system that was designed to kill him young. He is fit, both physically and mentally, and he brings a sense of humor and intense curiosity to all that he does. He would, and does, tell anyone he encounters that education has altered his worldview; it has expanded his horizons beyond the prison walls.

Prior to this experience, I would not have said that I had led a sheltered life, but clearly, with all I saw, all the stories I heard while teaching at NHSP, that would be a lie. I was sheltered, and I lived a life with opportunity; for me, college was a given and a must. In contrast, I met men, most of whom were 
still fairly young, who had literally grown up in the system. I met a man in his later thirties, who had been incarcerated off and on since he was nine. That this man was sitting in a college classroom was testament to his hard work. He had gotten his GED in prison, no simple task when you consider his fragmented educational background along with the recognition of undiagnosed significant learning disabilities. The work was painstakingly slow; it had taken him years, but he made it. His essays were thoughtful and soul searching, and his response to the essayists he encountered had a profound affect. He wrote about oppression and second-class status and where it could lead if it were not for what he was learning and the changes that were taking place within him. He was one of the many success stories I encountered during my tenure; he is one of the many who have found education the key to success in the outside world. They have grown as individuals, they are better equipped to solve problems; they have developed an understanding of the world; they are employable.

My professional experience confirms that an education can never be taken away. Once a concept is internalized, it is there for retrieval at any time. It changes the way you see the world; it changes the way you see yourself. My students have often heard me launch into a discussion about the need to allow learning to happen, to encourage it. It is vital. People who are educated are obviously better prepared to become contributing members of society. It seems so simple.

As a society, it would be in our best interest to help those who are incarcerated to find better ways to survive in this cruel world. So many of the men I encountered in the prison system were undereducated, and came from homes that were unable to provide the basic needs for human survival, much less a nurturing environment that modeled the kind of behavior society values. These men were clearly culturally and educationally deprived, living in an environment that is devoid of stimuli. This is a dangerous combination.

Intervention is necessary, not a luxury. How can we expect prisoners to re-enter society as productive individuals if we are not willing to help with the necessary acquisition of skills and information? To people who say convicted murderers do not deserve to be educated, Eddie Ellis, former prisoner and president of the Community Justice Center in Harlem says, "That's a very short-sighted, narrow-minded and self-serving argument. Why? Because most are ultimately released, and people who acquire education are less likely to become recidivists" (Pfeiffer, 2000). That the recidivism is clearly affected by 
higher education is not in dispute, but while being in possession of a college degree contributes to a lower recidivism rate, the general public does not want tax dollars paying for prisoners to attend college (ibid.).

However, reduced recidivism is not the only benefit. Prison officials report that the prisoners who are involved in educational programs are more easily managed, present fewer problems, and are less of a threat to their counterparts and staff. So, why is it that these programs have been hit so hard?

The public has been duped. They have been led to believe that crime is out of control in this country, and yet the crime rate is lower than it has been since the 1950s. The public has been coerced into believing that we must "get tough on crime," and that means longer sentences, super max prisons, and an attitude that says we should just let men and women rot in prison. The reality, however, is quite different. We know for a fact that education does make a difference. The data are there to support the contention that when we offer the opportunity for men and women in prison to explore the world beyond the walls, they are changed in ways that can make all the difference in the world.

In 1994, when federal funding for higher education in the United States was taken away from prisoners, and Pell grants were no longer an option, I was saddened beyond belief. It seemed so short-sighted. But, I was not surprised. I had learned much about the system during my tenure at NHSP. I had watched the clash between education and security. I witnessed educational events being cancelled on a moment's notice for "security reasons." I had seen guards flex their muscle and return men to their cells without provocation, thereby undermining the educational process, and I had watched as men were treated with disrespect and left with little or no human avenue for defense. I have questioned the value of this course of action. With so many men and women incarcerated in the United States today, and considering the very real prospect that most will be returned to the same neighborhoods that we walk through every day, why would we not as a society want them to be as prepared as they can be to make that transition?

As anyone who has ever done time knows, prison is a boring, mind-numbing place. Prisons provide a perfect breeding ground for anger, frustration, and apathy, but I have seen what can happen when people are offered a role in their future. Goethe said, "If you treat an individual as he is, he will stay as he is, but if you treat him as if he were what he ought to be and could be, he will become as he ought to be and could be." These men and women, when treated as students and writers, have much to gain. When given the opportunity, those 
with desire, those with a willingness to do the necessary work can alter their course. Society can only benefit from this enlightenment. We should be funding programs that will enhance each prisoner's chance of survival in the world upon release. We should be encouraging learning at every opportunity rather than warehousing humans to the benefit of no one; it is expensive and the rate of success is abysmal. After all, what have we got to lose?

\section{REFERENCES}

Pfeiffer, M.B. (2000, 17 November). "Inmate College Programs Now Rare." Poughkeepsie Journal. 